UNIVERSIDADE DE SÃO PAULO

ESCOLA DE ENGENHARIA DE LORENA

Desenvolvimento de sorvetes probióticos à base de extrato solúvel de soja

LUDMILA CARRIL FERNÁNDEZ

Lorena - SP

2015 


\section{Desenvolvimento de sorvetes probióticos à base de extrato solúvel de soja}

Dissertação apresentada à Escola de Engenharia de Lorena da Universidade de São Paulo para obtenção do título de Mestre em Ciências do Programa de Pós-Graduação em Biotecnologia Industrial na área de concentração de Microbiologia Aplicada.

Orientador: Prof. Dr. Ismael Maciel de Mancilha

Edição reimpressa e corrigida 
Ficha catalográfica elaborada pelo Sistema Automatizado da Escola de Engenharia de Lorena, com os dados fornecidos pelo(a) autor(a)

Fernández, Ludmila Carril

Desenvolvimento de sorvetes probióticos à base de extrato solúvel de soja / Ludmila Carril Fernández; orientador Ismael Maciel de Mancilha - ed. reimp., corr. - Lorena, 2015.

$86 \mathrm{p}$.

Dissertação (Mestrado em Ciências - Programa de Pós Graduação em Biotecnologia Industrial na Área de Microbiologia Aplicada) - Escola de Engenharia de Lorena da Universidade de São Paulo. 2015 Orientador: Ismael Maciel de Mancilha

1. Extrato solúvel de soja. 2. Lactobacillus delbrueckii ufv h2b20. 3. Sorvete probiótico. I. Título. II. Mancilha, Ismael Maciel de, orient. 


\section{RESUMO}

FERNANDEZ, L. C. Desenvolvimento de sorvetes probióticos à base de extrato solúvel de soja. 2015. 86p. Dissertação (Mestrado em Ciências) - Escola de Engenharia de Lorena, Universidade de São Paulo, Lorena, 2015.

Sorvetes são alimentos que apresentam grande potencial como veículo de espécies de micro-organismos probióticos, tendo em vista que apresentam elevada aceitabilidade em todas as faixas etárias. Os alimentos elaborados a base de soja se destacam no mercado devido às inúmeras evidências científicas sobre seus efeitos benéficos à saúde humana. Desta forma, no presente trabalho objetivou-se o desenvolvimento de sorvetes probióticos formulados com diferentes extratos solúveis de soja (in natura e fermentados), utilizandose a cepa Lactobacillus delbrueckii UFV H2B20. Primeiramente, avaliou-se o desempenho fermentativo ( $\mathrm{pH}$ e acidez titulável) de 5 cepas de Lactobacillus em meio formulado com os extratos solúveis de soja ESL e ES60, cujos resultados demonstraram que estes extratos são adequados para a formulação de meios de fermentação. $\mathrm{Na}$ sequência foram processados sorvetes probióticos formulados com os respectivos extratos in natura (ESL e ES60) e fermentado (ESL F e ES60 F) por Lactobacillus delbrueckii UFV H2B20. Nos sorvetes confeccionados com os extratos na forma in natura, uma suspensão de células da referida cepa foi adicionada à calda previamente ao processo de batimento e congelamento. Os sorvetes foram estocados a $-23{ }^{\circ} \mathrm{C}$ por 5 meses e avaliados periodicamente quanto às características físico-químicas ( $\mathrm{pH}$, acidez titulável, composição centesimal e overrun), microbiológica (viabilidade celular) e sensoriais. Os resultados demonstram que a cepa de Lactobacillus avaliada foi capaz de fermentar os açúcares presentes nos respectivos extratos de soja produzindo ácido láctico, atingindo a concentração de $0,90 \%$ no meio formulado com o extrato de soja desengordurado ES60. Os sorvetes confeccionados com os respectivos extratos fermentados apresentaram diferenças significativas $(\mathrm{P}<0,05)$ quanto ao $\mathrm{pH}$ e acidez titulável em relação aos sorvetes com extratos in natura, atingindo valores de $\mathrm{pH}$ inferiores a 4,0 com produção máxima de ácido láctico de 1,36\%. A composição centesimal dos sorvetes desenvolvidos está de acordo com o padrão mínimo estabelecido pela ANVISA, apresentando uma composição média de 2,5\% de proteínas, 5,0-6,0\% de gordura e 36,0\% de sólidos totais. As características probióticas dos sorvetes estudados foram preservadas, apresentando contagens de células viáveis superiores a $10^{6} \mathrm{UFC} / \mathrm{g}$, com redução do número de células inferior a um ciclo logarítmico ao longo de 150 dias de estocagem a $-23^{\circ} \mathrm{C}$. A análise sensorial revelou que os sorvetes formulados com os respectivos extratos in natura não apresentaram diferenças significativas entre si $(\mathrm{P}>0,05)$ para os atributos avaliados e apresentaram maior aceitabilidade, sendo o sorvete formulado com o extrato ESL o que obteve maior aceitação, com médias acima de 6,0 correspondente a "gostei ligeiramente". Os resultados demonstraram ainda que a fermentação dos extratos interferiu negativamente nas características sensoriais dos respectivos sorvetes, apresentando diferenças significativas em relação aos extratos in natura, além de resultar nos menores escores de aceitação, tendo o sorvete fermentado ES60 F sido avaliado como "desgostei moderadamente". Estes resultados permitem concluir que o extrato solúvel de soja é um insumo adequado para a formulação de meio de cultivo de espécies de microorganismos probióticos, além de apresentar potencial para a confecção de sorvetes probióticos mediante adaptações da tecnologia de produção de gelados comestíveis.

Palavras-chave: Extrato solúvel de soja, Lactobacillus delbrueckii UFV H2B20, sorvete probiótico. 


\begin{abstract}
FERNANDEZ, L. C. Development of probiotic ice cream from soluble soybean extract. 2015. 86p. Dissertation (Master of Science) - Escola de Engenharia de Lorena, Universidade de São Paulo, Lorena, 2015.

Ice creams are foods that have great potential as a vehicle for species of probiotic microorganisms due to its high acceptability by all age people. Foods made with soybeans byproducts stand out in the market due to the numerous scientific evidences that show its beneficial effects on human health. Therefore, this study aimed to the development of probiotic ice cream formulated with different soybean soluble extracts (in natura and fermented), using the strain Lactobacillus delbrueckii UFV H2B20. Primarily, it was evaluated the fermentation performance ( $\mathrm{pH}$ and titratable acidity) of 5 Lactobacillus strains in media formulated with soluble soybean extracts ESL and ES60 (Olvebra ${ }^{\circledR}$ ), and the results showed that these soybean byproducts are suitable for the formulation of fermentation media. The probiotic ice cream were formulated with the soybean extracts in natura (ESL and ES60) and fermented (ESL F and ES60 F) by Lactobacillus delbrueckii UFV H2B20. For the manufacture of ice cream with the soybean extracts in natura, a cell suspension was added to the basic ice cream formulation before beating and freezing procedures. The ice creams were stored at $-23^{\circ} \mathrm{C}$ for 5 months and evaluated periodically regarding the physico-chemical characteristics $(\mathrm{pH}$, titratable acidity, chemical composition and overrun), microbiological (cell viability) and sensorial evaluation. The results shown that the Lactobacillus strain were capable to metabolize the sugars presented in the soluble soybean extracts producing lactic acid reaching a concentration of $0.90 \%$ in the media formulated with defatted soybean extract ES60. The ice creams made with fermented extracts showed significant differences $(\mathrm{P}<0.05)$ regarding $\mathrm{pH}(<4,0)$ and titratable acidity $(1,36 \%)$ in relation to the ice creams manufactured with extracts in natura. The results concerned to the chemical composition of the ice cream, showed that the values obtaneid are in accordance with those stablished by ANVISA, presenting an average composition of $2.5 \%$ protein, $5,0-6,0 \%$ fat and $36,0 \%$ total solids. The probiotic characteristics, of the formulated ice creams, were preserved presenting viable cell counts greater than $10^{6} \mathrm{UFC} / \mathrm{g}$, and a decreasing in the cell number lower than one log cycle after 150 days of storage at $-23{ }^{\circ} \mathrm{C}$. Regarding the sensorial evaluation, the results revealed that the ice creams formulated with soybean extracts in natura showed no significant differences between them $(\mathrm{P}>0.05)$ for the evaluated attributes and they showed higher acceptability. The ice cream formulated with ESL extract presented higher acceptance, with average notes greater than 6.0, corresponding to "like slightly". The results also showed that the fermentation of the extracts influenced negatively on the sensory properties of the ice cream, showing significant differences regarding the ice cream made with the extracts in natura, and lower acceptance scores, being the fermented ice cream ES60 F evaluated as "moderately disliked". These results indicate that the soluble soybean extracts evaluated in the present work are suitable for culture medium formulation for probiotic microorganisms, and also shown its potential for making probiotic ice cream by adaptation of the technology.
\end{abstract}

Keywords: Soluble soy extract, Lactobacillus delbrueckii UFV H2B20, probiotic ice cream. 